\title{
Review on Challenges and Opportunities of Milk Production in Ethiopia
}

\author{
Neamn Gebreselassie \\ Department of Animal Production and Technology, Adigrat University, P.O. Box: 50, Adigrat, Ethiopia
}

\begin{abstract}
This review is conducted to assess the Opportunities and Challenges of Milk production in Ethiopia. In Ethiopia the dairy industry plays an enormous role in ensuring food security and creating rural employment in the highland and lowland areas. In Ethiopia, dairying is experienced throughout the country by a large number of rural and urban producers. Indigenous breeds of cows are generally considered as low milk producers. However, they are the major source of milk in Ethiopia that accounts for $97 \%$ of the total milk production in the country. The average milk production from indigenous cows is 1.85 litters/head per day and ranged from 1.24litter in the rural lowland areas to 2.31 liter in the rural highland areas. There are ample opportunities for dairy development which includes large state of range land, huge livestock population, diverse cattle genetic resources, existence of different agroecologies suitable for milk production, rapid increase human population and urbanization. Despite of the opportunities existed for dairy development in the country there are also technical and non technical constraints which hinders the dairy development so far in the country. These constraints include inadequate feed and water, poor health service, poor housing system unplanned breeding system, inadequate extension service, poor genetic resource, fragile linkages between extension service providers and milk producers as well as inadequate infrastructure are some of the problems for dairy production in Ethiopia. Hence besides the opportunities existed there should be also strong institutional support for dairy producers and cooperatives, and improving access to services like credit facilities, road and market infrastructure, land, water, feed, health, extensive AI service etc must receive appropriate awareness in order to advance milk production in the country.
\end{abstract}

Keywords: Challenge, Ethiopia, Milk, Opportunity

DOI: $10.7176 /$ FSQM/95-04

Publication date:March $31^{\text {st }} 2020$

\section{INTRODUCTION}

Ethiopia stands first in Africa by its livestock population with 53.99 million cattle, out of which female cattle constitutes about $55.48 \%$ and $44.52 \%$ are males. $98.95 \%$ of the total cattle are local breeds and the remaining are hybrid $(0.94 \%)$ and exotic breeds $(0.11 \%)(\mathrm{CSA}, 2013)$. Over $60 \%$ of the cattle and sheep reported to be found in the highlands, while goats and camels are predominant in lowlands (CSA, 2013). Ethiopia holds large potential for dairy development. In Ethiopia dairy production depends mainly on indigenous livestock genetic resources; more specifically on cattle and then goats, camels and sheep. Cattle has the largest contribution (81.2\%) of the total national annual milk output, followed by goats $(7.9 \%)$ camels $(6.3 \%)$ and sheep (4.6\%) (CSA, 2009). Cattle found in Ethiopia are mostly Zebu. However, exotic breeds such as Holstein Friesian and jersey have been imported for many years and cross breed with the indigenous cattle breeds. Cross breed and high grade cows varying in their exotic gene level are found in many governmental and non-governmental organizations, cooperatives, small scale and large scale commercial dairy farmers (Yosephetal.,2002;2002b). Milk and milk products contributed $36-46 \%$ to the total house hold income in some area (Asrat etal, 2013). Milk is one of the most complete foods in nutritional terms; it is rich in nutrients essential for growth and maintenance of a healthy life (Vilela, 2002). The importance of adding milk to the human diet is because of its richness in proteins, fats, carbohydrates (lactose), mineral salts, vitamins, conjugated linoleic acid, sphingomyelin, butyric acid, among other substances, which provide immunologic protection and essential nutrients to its consumers (Sordilloet al., 1997; Oliveira et al., 1999). Ethiopia has a huge potential for dairy development in Africa. The large and diverse livestock genetic resources, existence of diverse agro-ecologies suitable for dairy production, increasing domestic demand for milk and milk products, large livestock population, increasing human population, urbanization trends and rising household incomes indicate the potential and opportunities to increase milk production in Ethiopia (Azage etal., 2013). Despite its potential for dairy development, productivity of the dairy sector in Ethiopia is generally low and the direct contribution it makes to the national economy is limited. The most important constraints associated with milk production as ranked according to their importance by the farmers were feed shortage, shortage of water, access to land, disease prevalence, poor genetic potential of local cows for milk production, inadequate artificial insemination services, and shortage of farm labor. The total productions of milk in the areas are affected by the interaction of these constraints (Assaminew and Eyassu, 2009). Hence this paper is aiming at reviewing the opportunities and challenges faced for Milk production in Ethiopia. 


\section{LITERATURE REVIEW}

\subsection{Milk Production performance}

In Ethiopia, dairying is practiced all over the country by a large number of small or medium or large-sized, subsistence or market-oriented farms. Indigenous breeds of cows are generally considered as low milk producers. However, they are the major source of milk in Ethiopia that accounts for $97 \%$ of the total milk production in the country (CSA, 2008). According to (Tsehay, 2002), based on their location, milk production systems can be classified into three: urban, pre-urban and rural milk production systems. In general, urban dairy production system are placed in cities and towns, with small or no access to grazing land and small feeding conditions which focus on the production and sale of fluid milk, using the available human and capital resources. Urban dairy production system have a better access to inputs and services provided by the public and private sectors, and use intensive management compared to other systems (Azege, etal., 2013). The national cow milk production estimated by CSA (2011) is 4.06 billion litter (excludes milk suckled by calves). In general, milk production in Ethiopia is low. According to Azege, etal., 2013) the average milk production from indigenous cows is 1.85 litres/head per day and ranged from 1.24 in the rural lowland agro-pastoral system to 2.31 in the rural highland system. The average daily milk production for crossbred dairy cows is higher in urban (10.21-15.9 litres/head per day) than peri-urban (9.5 litres/head per day) systems. Lactation milk yield of indigenous dairy cows ranged from 271.4 litres/head in the rural lowland agro-pastoral system to $434.8 \mathrm{~kg} /$ head in the peri-urban system with an average lactation length of 7.8months.

Table 1: Comparison of average daily and lactation milk yield in Ethiopia, Newzeland, Germany and USA (FAO, 2010; FAOSTAT, 2010)

\begin{tabular}{|l|l|l|l|l|}
\hline & Ethiopia & Newzeland & Germany & USA \\
\hline Average daily milk Yield /cow(in kg) & 1.85 & 11.2 & 19.5 & 23 \\
\hline Average yearly lactation/cow(in kg) & 269 & 3635 & 7083 & 9593 \\
\hline
\end{tabular}

Source: (FAO, 2010; FAOSTAT, 2010)

\subsection{Opportunities of Dairy cattle production}

In Ethiopia, there are ample opportunities for dairy development. The large and diverse dairy animals genetic resources adapted to the wide and diverse agro-ecologies, establishment of several structures and service centers such as veterinary health and artificial insemination (AI) centers, extensive service of agricultural extension, high demand for consumption of dairy products, huge human population with long-standing tradition of consumption of dairy products, high rate of urbanization and income growth, availability of trained manpower, research institutions and technologies shows that the country has good opportunity for dairy development (Azege, et al., 2013).

\subsection{Challenges of Dairy cattle production}

Dairy production is constrained by multifaceted factors, though the nature and magnitude of the problems vary between production systems and agro-ecologies. Some are cross-cutting that can have influence on dairy production regardless of dairy production system and agro-ecologies; others are system specific. The major constraints are described below.

2.3.1. Genetic limitation: The main problem of milk production in the country is that of the poor genetic potential of the indigenous cattle, which gives rise to low milk output. Milk production is as low as 0.5 to 2 liters per day over a lactation period of 160 to 200 days. Improving the feeding, water availability and health care of the indigenous cattle did not increase the quantity of milk per day to allow the animals to be used for commercial market-oriented milk production. The current specialized dairy breeds are a result of a long period of selection program. If improvement of the local Ethiopian breeds for milk production is targeted, then it is important to have a well designed selection program in place for a few selected promising breeds (ZelalemYetal., 2011)

2.3.2. Inadequate Animal feed and Water resources: The primary constraints to increased milk production under all dairy production systems are inadequate feed resources, poor pasture development and the ever increasing feed prices. Farmers tend to keep cattle at stocking rates that far exceed the carrying capacity of their grazing lands. This has resulted in degraded pastures and eroded soils. Stock numbers are not normally reduced in the dry season leading to grazing lands becoming progressively overgrazed. In the dominating crop/livestock production system, producers supplement the feeding of their dairy cows with crop residues and farm by-products from their farms. In some cases, during the dry season, these feedstuffs can be the only feeds available to the animals. However, the improvement of the utilization of these feedstuffs through physical and chemical processing methods to increase the availability of nutrients is only practiced on a limited number of farms. the main reasons of feed shortage is cultivation of grazing lands, declining yields of grazing land and increase of livestock population. Shrinking sizes of the grazing lands driven by the expansion of land cultivation was reported to be the leading reasons for feed shortage. Declining yield and carrying capacity of the grazing lands was also the other important impediment in adequate supply of feeds. Increases of human and livestock population and drought are also mentioned to cause 
feed shortage (Minale etal., 2015). From the fact points of view, quantitative and qualitative shortage of feed and fodder affects the performance of milking animals, through under feeding animals in general; in particular, it affects milk production negatively. The cause for shortage of feed may be due to the fact that most farmers had small grazing land for animals; this was also true most natural pasture areas are converting to crop production. Moreover, population numbers are becoming increase over time in turn; overgrazing was common due to inadequate use of natural pasture and crop residues and by-products; and lack of knowledge in improved forage (legumes, grasses, and crops-forage) in conserving and managing(Tsegay etal., 2015). The feed shortage is mostly face during the month between May and June as well as between December and February and most of the water sources, except channel for transporting water are found about 1 to $30 \mathrm{~km}$ from the households to vary according on the season (Kedija, 2007). To deal with the problem the water harvesting practice is not developed in the areas yet. Above and beyond that, the shortage of water is highly make worsen through lengthened dry seasons and repeated drought. The backward livestock watering systems which are performed at every two days and every three days during the dry and wet season respectively for cattle cannot adequately concentrate on the production of milk in the areas (Adane, 2009).

2.3.3. Limited access and high cost of dairy heifers/cows: The improved crossbreed, grade and pure exotic dairy cattle are usually in short supply and when available, the high cost is a major problem. The few government crossbreed heifer multiplication centers that used to distribute in-calf crossbreed heifers to producers at reasonable prices have been sold after the introduction of the privatization policy. Prices of crossbreed cows and heifers are now unaffordable by the poor and the average smallholder farmers that would have liked to engage in the dairy business (ZelalemYetal., 2011).

2.3.4. Absence of an operational breeding strategy and policy: The absence of effective breeding programs is a major constraint to the dairy development. The AI service has been inefficient for different reasons in rural areas where smallholder farmers predominate. As reported by Shiferaw et al., 2003 some of these reasons include: inappropriate infrastructure, managerial and financial constraints, inefficient heat detection and improper timing of insemination, embryonic death and very small number of AI technicians compared with the number of cows in a given area. Hiskias et al., 2010 indicated that the Ministry of Agriculture assigns one AI technician to serve farmers of one district. However, taking into consideration the number of dairy producers, the number of female cattle of reproductive age, and the required facilities (logistics) available to AI technicians, it is practically impossible for an AI technician to satisfy the demands of all the producers in a given district. Consequently, the general productivity of the dairy herd kept by smallholder producers is very low. In spite of its sizeable livestock resources and the accompanied benefits that the country is supposed to derive from the industry, Ethiopia does not have a functional breeding policy. Most of the cattle breeding activities have been executed under strategies set by various individual organizations/institutions. Furthermore, the current conducive policy for investment opportunities is not supported by an operational breeding policy that determines the type of genetic material to be brought into the country in order to achieve the targeted genetic improvement in the different farming systems and agro-ecologies.

2.3.5. Inadequate Veterinary service provision: The prevalence of various animal diseases, tick borne diseases, internal parasites and infectious diseases affect dairy development programs in varying scales, depending on ecological zones and management levels. The animal health services provided are inadequate; the cost of drugs and ascaricides is very high, while the diagnostic services are not readily available to the dairy farmer. This is partly attributed to the insufficient budget allocated to veterinary services (GRM International BV, 2007). Lema et al., (2000) also reported that an overall disease occurrence of 46.8 and 33.6 percent in urban and peri-urban dairying in the central highlands, respectively. The same authors also reported the overall disease prevalence rates of 20.8, 13.1 and 10.7 percent during the dry, short rainy and long rainy seasons, respectively with an overall annual mortality rate of 4.2 percent.

2.3.6. Unavailability of land: The problem of inadequate feed is as a result of the limited land available for pasture establishment, especially in the productive highland zones that have a potential for dairy development. According to (Azege, etal., 2013; Sintayehu, et al., 2008 land scarcity is also another major problem in urban and pre-urban dairy farming system.

Weak linkages between research, extension service providers and technology users: Weak linkages between research, extension, and technology users are one of the critical factors that have hindered dairy development in the country. This weakness stems partially from the absence of sound linkage policies in the agricultural knowledge generation and transfer systems (ZelalemYetal., 2011).

Inadequate extension and training service: Effective and adequate extension services and advice on animal nutrition and feeding management, reproduction, hygiene, farm management and dairy production efficiency are not always available to the dairy farmer. A shift towards a developed dairy industry requires more support from advisory services and more effective links with research services (ZelalemYetal., 2011).

Milk market related constraints: There are no promotional activities being carried out by various government offices to portray milk as a highly nutritious and essential food for the health of the nation. There are also no price 
regulatory mechanisms in place that can make such an important food item easily available and affordable to a large segment of the population. As earlier mentioned, there are no functional quality control and payment systems in the country (ZelalemYetal., 2011). .

Limited availability of credit to the Dairy farmer: Many farmers are aware of the existence of improved technologies that can offer them higher returns as compared with their conventional practices. However, most of the poor farmers do not have the financial means required to make the initial investment and acquire the associated technological inputs. Financial support or credit facilities to smallholder farmers who intend to enter into commercial dairy farming are very much limited. The importance of establishing credit facilities is a crucial step to the country's dairy sector as indicated in the livestock development master plan (GRM International BV, 2007).

\section{CONCLUSSION}

It is well known that milk is one of the most complete foods in nutritional terms; it is rich in nutrients essential for growth and maintenance of a healthy life. Dairying constitutes an important part of the Ethiopian smallholder crop/livestock farming system. The country is known to have the highest number of cattle in Africa, making it one of the biggest potential producers of milk and milk products in Africa. However due to the existence of several dairy constraints milk production in the country is still at its infant stage. The demand and supply for dairy products is not yet balanced due to this the country is still imported significant amount of dairy products from abroad. There are also small numbers of dairy processing plants in the country which are inaccessible to farmers to deliver their fresh milk easily. The rural dairy producers are also faced many problems in improving the dairy production. Poor infrastructure network, inadequate provision of veterinary services and lack of continuous supply of animal feeds throughout the year, poor animal genetic resource, poor institutional linkage are some of the problems faced by farmers in the field. There is a need for government and non-governmental organizations to hugely invest in the dairy industry and transform the activity into a lucrative business, which will contribute to the highest in the livestock sector GDP through exporting of live dairy animal and its processed products.

\section{RECOMMENDATION}

After reviewing the challenges and opportunities of the Ethiopian Dairy sector currently, it might be appropriate to consider the following research, development, and policy as well as crosscutting issues in order to make improvement interventions for the development of the dairy industry.

- Improving the use of pasture through appropriate grazing land management systems.

- Developing milk processing and preservation technologies appropriate to the various major agro-ecological zones of the country

- Improving the housing system and provision of adequate veterinary service

- Enhancing infrastructures and improving the genetic resource of indigenous dairy animals through cross breeding.

\section{Conflict of interests}

- The author did not declare any conflict of interest.

\section{ACKNOWLEDGEMENTS}

I wish to express my sincere appreciation to my almighty god for unreserved support during this review work. Without the support of him anything is impossible.

\section{REFERENCES}

Adane, 2009. Value Chain Analysis Of Milk And Milk Products In Borana Pastoralist Area, Addis Ababa, Ethiopia. Asaminew Tassew And Eyassu Seifu, 2009. Smallholder Dairy Production System And Emergence Of Dairy Cooperatives In Bahir Dar Zuria And Mecha Woredas, Northwestern Ethiopia. World Journal Of Dairy \& Food Sciences 4 (2): 185-192, 2009. Andassa Livestock Research Center, Bahir Dar, Ethiopia.

Asrat, A; Zelalem, Y. and Ajebu, N., 2013.Characterization Milk Production System in and around Boditti, South Ethiopia.J.Irrd.25(10).at the "Successes in African Agriculture" conference held on 1-3 December, 2003.

Azage Tegegne, Berhanu Gebremedhin, Dirk Hoekstra, Berhanu Belay and Yoseph Mekasha, 2013. Smallholder dairy production and marketing systems in Ethiopia: IPMS experiences and opportunities for market-oriented development; Improving Productivity and Market Success of Ethiopian Farmers Project (IPMS) International Livestock Research Institute (ILRI), Addis Ababa, Ethiopia.

CSA (Central Statistical Agency) (2008). Report on Livestock and Livestock Characteristics (private peasant holdings).Statistical bullet in 446, volume 2.Federal Democratic Republic of Ethiopia Central Statistical Agency, Addis Ababa, Ethiopia.

CSA (Central Statistical Agency) (20011).The World face book, Africa, Ethiopia.https://www.cia.gov/library/publications/theWorld face book/goes/et. html. Accessed on 15 Jan 
2011.

CSA (Central Statistical Agency) (2009).Agricultural Sample Survey 2008/09. Report on livestock and livestock characteristics. Statistical bullet in 446.Addis Ababa, Ethiopia.CSA (Central Statistical Agency) (2010/11).Agricultural Sample Survey 2010/11.Vol.2. Report on livestock and livestock characteristics. Statistical bullet in Addis Ababa, Ethiopia.

CSA (Central Statistical Agency)(2013). FDRE Central Statistical Agency. Agricultural Sample Survey (2012/13)(2005).discussionpaper.AddisAbaba:MOA(AmharaVrrsion).document,AddisAbaba,Ethiopia:Mini stryofAgriculture/AFRDRD/AFRDT.FoodandAgricultureOrganization//SSFF. 105P.

FAO (Food and Agriculture Organization) (2010). Livestock Sector in brief in Ethiopia. Food and Agriculture Organization of the United Nations.Livestock information, sector analysis and policy branch.AGAL may, 2004.production (ESAP), Addis Ababa, Ethiopia, pp300.

FAOSTAT (Food and Agriculture Organization of the United Nations) (2010).Milk Production.https://faostat. fao.org/site/569/Desktop.Defoult,aspx? Page ID=569\# ancor. Accessed on 20 Feb 2012.

GRM International BV. 2007. Livestock Development Master Plan Study. Phase I Report - Data Collection and Analysis. Volume 1 - Dairy.

Kedija Husien, 2007. Characterization of milk production system and opportunity for market orientation: A Case Study of Mieso District, Oromia Region, Ethiopia. M.Sc. Thesis. Haramaya University, Ethiopia.

Lemma, T., Tegegne, A., Puskur, R., Ranjitha, P. \& Hoekstra, D. 2008. Moving Ethiopian smallholder dairy along a sustainable commercialization path: missing links in the innovation systems: Improving Productivity and Market Success (IPMS) Project, ILRI, Addis Ababa, Ethiopia.

Minale Getachew and Yilkal Tadele,2015. Constraints and Opportunities of Dairy Cattle Production in

Chencha and Kucha Districts, Southern Ethiopia. Journal of Biology, Agriculture and HealthcareVol.5, No.15,P40

Oliveira, C. A. F.; Fonseca, L. F. L. and Germano, P. M. L. 1999.Aspectosrelacionados à produçãoqueinfluenciam a qualidade do leite. HigieneAlimentar 13:10-13.

Shiferaw, Y., Tenhagen, B.A., Bekana, M. \& Kasa, T. 2003. Reproductive performance of crossbred dairy cows in different production systems in the central highlands of Ethiopia. Trop Anim Health Prod. 25, 551-561.

Sordillo, L. M.; Shafierweaver, K. and Derosa, D. 1997. Immunobiology of mammary gland. Journal of Dairy Science 80:1851-1865.

Tsegay Lijalem Agegnew Asefa Ashenafi Sharo, 2015. Challenges and Opportunities of Dairy Cattle Production in selected Districts of Sidama Zone, Southern Ethiopia. J. Food Science and Quality Management V.44:P9.

Tsehay, R. 2002. Small scale Milk Marketing and Processing in Ethiopia. In: RangnekarD.andThrope W. (eds). Small holder dairy Production and marketing opportunities and constraints proceedings of a South workshop held at NDDP, Anand, India, 13-16.March.2001.

Vilela, D. 2002. Aimportânciaeconômica, social e nutricional do leite. RevistaBatavo 3:17-18

Zelalem Yilma Emmannuelle Guernebleich Ameha Sebsibe, 2011. A Review of the Ethiopian Dairy Sector pp54. 